\title{
Development of an Assessment to Measure Science Process Skills for the Interaction of Living Things with Their Environment in Junior High School
}

\author{
${ }^{1}$ Della Oktavia, ${ }^{2}$ Abdul Aziz Bin Mustamin, ${ }^{3}$ Ahmad Walid \\ ${ }^{1}$ Faculty of Tarbiyah and Tadris, IAIN Bengkulu \\ ${ }^{2}$ Science Tadris Study Program, IAIN Bengkulu \\ Email Correspondence: dellaoktavia1015do@gmail.com
}

\author{
Article Info \\ Article History \\ Received: 03 August 2021 \\ Revised: 19 August 2021 \\ Published: 25 September \\ 2021 \\ Keywords \\ Development assessment; \\ science process skills, \\ living being interaction.
}

\begin{abstract}
This study aims to develop an assessment to measure science process skills in the interaction of living things with their environment. The research method used is a research and development method consisting of 8 steps, namely research and initial information collection, planning, initial product format development, small-scale trials, product revisions, initial trials, and final products. The trial subjects in this research and development are expert subjects, namely assessment experts, material experts and linguists, as well as the subjects of class VII SMPN students in Bengkulu City as product users. Data were analyzed descriptively qualitatively and quantitatively. Feasibility assessment by three validator experts developed on the assessment aspect of $89 \%$, material aspect of $93 \%$, and language aspect of 93\%, overall was declared very feasible with an average of $92 \%$. This shows that the assessment of science process skills to measure science process skills is stated to be very suitable to be used to measure the level of students' science process skills. The assessment developed to measure Science Process Skills (KPS) is the science assessment, where in the development of the science assessment it uses formative assessment because this assessment is given to every lesson and can be carried out on sub-subjects or each subject. In the development of this formative assessment, multiple choice tests were developed.
\end{abstract}

(C) 2021 Science Education Study Program FKIP Unisla Lamongan.

Citations: Walid, A., Oktavia, D., \& Mustamin, A. A. B. (2021). Development of an Assessment to Measure Science Process Skills for the Interaction of Living Things with Their Environment in Junior High School. Science Education and Application Journal, 3(2), 113-118.

\section{INTRODUCTION}

In the 2013 Curriculum the learning process emphasizes providing direct experience to learn and develop competencies to care, examine, and understand the natural surroundings scientifically. Education is also the right and obligation of every Indonesian citizen. This is explained in the National Education System Law No. 20 of 2003 Article 5 Paragraph 1 states that every citizen has the same right to obtain quality education. The 1945 Constitution Article 31 Paragraphs 1 and 2 also explains that every Indonesian citizen has the right to education, and every citizen is obliged to attend basic education and the government is obliged to pay for it (Kartika, Ardia Tita, et al., 2020).

The most basic ability as a basis for mastering higher abilities and science skills is the ability to understand concepts. Understanding the concept of Science provides an understanding that the materials taught to students are not just rote. By understanding the concept of science students are expected to be able to better understand the concept or subject matter itself, the interrelationships between concepts, and use concepts in solving problems. Understanding the concept is one of the goals of learning science that absolutely must be 
achieved because understanding a concept is very supportive for understanding the next concept, or in other words understanding a concept is a prerequisite for understanding the next concept. However, reports from international studies show the real reality of the quality of our education, especially at the junior high school level. So it can be said that people who have a positive self-concept towards themselves then maintain their abilities with positive feelings towards themselves, towards doubts about their abilities. and challenges in life, as well as resulting in low self-assessment in relation to others (Walid, Putra, \& Asiyah., 2019).

This is in accordance with the results of a survey from TIMSS (Third International in Mathematics and Science Study) in 2015 showing that the ability of Indonesian students in the field of Science is 36th out of 49 countries surveyed. Meanwhile, the 2018 PISA (Programme International for Student Assessment) survey report states that the performance of Indonesian students for Science is ranked 70 out of 77 countries evaluated (Stadler, Matthias, et al., 2020).

In the 2013 curriculum, it is explained that student assessment in the learning process is closely related to thinking skills. Students' thinking skills can be trained through providing meaningful experiences in the learning process. Students' thinking ability in building new concepts in science learning can be trained through the development of Science Process Skills (Skills) (Walters, Yvonne, \& Soyibo., 2001). Science Process Skills (KPS) are very important for every student as a provision to use the scientific method in developing science to acquire new knowledge or develop existing knowledge. The concept discovery process involves basic skills through scientific experiments that can be implemented and improved through laboratory activities as science process skills (Murniasih, L., et al., 2013).

The results of observations made by researchers in three junior high schools, namely SMP 1 Bengkulu City, SMP 8 Bengkulu City and SMP 19 Bengkulu City in class VII the material for the interaction of living things with their environment which contains Science Process Skills (KPS) is relatively low, this is evidenced by the analysis of the questions presented. conducted at SMPN 5 Bengkulu City shows that the average percentage of the Science Process Skills (KPS) indicator is $29 \%$ while from SMPN 8 Bengkulu City shows an average Science Process Skills (KPS) indicator of 23\% while from SMPN 19 Bengkulu City it shows that the average percentage of the Science Process Skills (KPS) indicator is 19\%.

Based on the description of the background of the problem, the researchers are interested in developing an Assessment of Science Process Skills for the Material of Interaction of Living Things with Their Environment in class VII at SMPN in Bengkulu City, so the title of this research is "Development of an Assessment to Measure Science Process Skills on the Interaction of Living Things with Their Environment. In SMP in Bengkulu City".

\section{METHODS}

This study uses the development model according to Borg \& Gall which was developed by Sugiyono. Borg \& Gall states that the research and development (R\&D) approach to education includes ten steps. Of the ten steps that exist, the researcher will limit it according to the needs of the research and development carried out. After simplifying the research and development procedure into eight steps only until the development stage. The research steps are as shown in the chart below: 


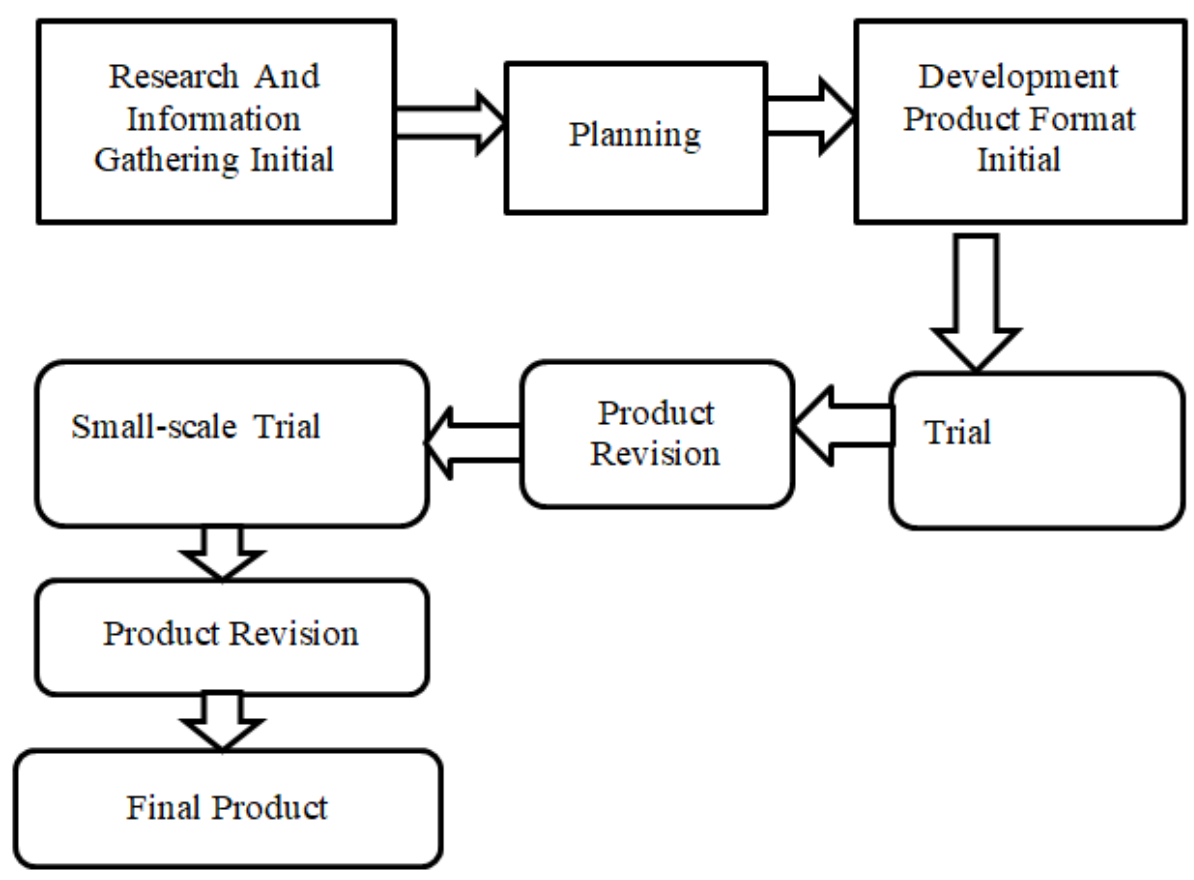

Figure 1. Research steps

Of the ten steps that exist, the researcher will limit it according to the needs of the research and development carried out. After simplifying the research and development procedure into eight steps only until the development stage.

\section{RESULTS AND DISCUSSION}

The product produced by researchers is in development (Research and Development) to measure science process skills, namely questions with material on the interaction of living things with their environment in class VII SMP. The procedure for developing this problem uses assessment development based on Borg and Gall. As for the steps, namely, collecting information and research, when the researchers conducted pre-research in 3 Junior High Schools (SMP) Bengkulu City, from the day of observation the researchers found out that the level of students' science process skills was still low, this was known when the researchers adjusted assessment used by the school with indicators of science process skills. The next stage that the researcher did was the research planning stage, where the researcher conducted a literature study to find the subject of the interaction of living things with their environment, to then make questions based on science process skills.

The next stage, which is carried out is the product development stage, at this stage the researcher develops an assessment product measuring science process skills, which is contained in the evaluation questions with indicators of science process skills. Next, the researcher conducted a limited trial validation phase, the product that had been designed was then validated with several experts including assessment experts, linguists, and material experts. The development carried out by the researchers resulted in an assessment product to measure the ability of science process skills on the subject of the interaction of living things with their environment which was adapted to the 2013 curriculum (K-13). Below are the results of the validation obtained by the experts, namely as follows:

1. Assessment Experts

Based on the results of the assessment development to measure science process skills that have been carried out, it is known that the results of the validator to obtain results of $89 \%$. So from the results of the validator referring to the conversion table, it can be concluded that the assessment to measure the developed science process skills is 
feasible to use or can be tested on students and no longer needs to be revised by researchers.

\section{Material Experts}

Validation is used to assess the materials that have been prepared in the assessment to measure science process skills. The learning aspect is assessed to determine whether the material presented is in accordance with $\mathrm{KI}$ and $\mathrm{KD}$ as well as learning objectives that include material in one semester. While the content aspect is to find out whether the content of the material is clear in its presentation. The results of the validation assessment from material experts can be seen in the table below.

Table 1. Questionnaire Expert Material

\begin{tabular}{ccccccc}
\hline Validator & $\begin{array}{c}\text { Number of } \\
\text { Items }\end{array}$ & Ideal & $\begin{array}{c}\text { Score } \\
\text { Obtained }\end{array}$ & $\%$ & Qualification & Description \\
\hline 1 & 9 & 45 & 42 & $93 \%$ & Very Eligible & $\begin{array}{c}\text { Needs } \\
\text { Revision }\end{array}$ \\
\hline
\end{tabular}

The results of the learning expert scores are categorized as $X>81 \%$ (very feasible), $61 \%<$ X $80 \%$ (adequate), $41 \%<$ X $60 \%$ (quite decent), $21 \%<$ X $40 \%$ (less feasible), and $X 20 \%$ (very less feasible). The percentage of the final product is $93 \%$ with very decent criteria.

3. Linguist

Aspects of language use to assess the vocabulary used, conformity with good and correct Indonesian language rules. This assessment aims to see whether or not the assessment is used for students. The results of the validation assessment of linguists can be seen in the table below.

Table 2. Questionnaire Language

\begin{tabular}{ccccccc}
\hline Validator & $\begin{array}{c}\text { Total } \\
\text { Item }\end{array}$ & Ideal & $\begin{array}{c}\text { Score } \\
\text { Obtained }\end{array}$ & $\%$ & Qualification & Description \\
\hline 1 & 9 & 45 & 42 & $93 \%$ & Very Eligible & $\begin{array}{c}\text { Needs } \\
\text { Revision }\end{array}$ \\
\hline
\end{tabular}

So from the results of the validator referring to the conversion table, it can be concluded that the assessment to measure the developed science process skills is feasible to use or can be tested on students and no longer needs to be revised by researchers.

The material experts get an average percentage of $93 \%$ with a decent category. Prior to the validation of the questions, the sentences used were still ambiguous. Then after validation, the questions that have been made have been well formulated, most of them have referred to the science process skills and the material asked according to the grade level. So the question is worthy to be tested. This is in accordance with KI, KD, learning indicators and indicators of science process skills, questions and answers are formulated correctly, the material asked is in accordance with the measurement objectives, level, type of school and grade level. In the teacher's response, obtaining an average percentage of $92 \%$ with a very decent category. The science assessment based on science process skills developed is in accordance with the question grid and the language used is good and correct.

\section{CONCLUSION}

Development of an assessment to measure science process skills was carried out based on eight of the ten stages of Borg \& Gall. And the development of science process skills on the material of the interaction of living things with the seventh grade environment in 
Bengkulu City, the questions developed are in accordance with the steps for preparing good questions.

The feasibility of a science assessment to measure science process skills can be seen from the results of expert validation, namely, assessment experts by $89 \%$ in the very appropriate category, material experts by $93 \%$ in the very appropriate category and linguists in $93 \%$ in the very appropriate category and In the teacher's response, obtained an average percentage of $92 \%$ with a very decent category. The science assessment based on science process skills developed is in accordance with the question grid and the language used is good and correct. So the question is worthy to be tested.

\section{SUGGESTIONS}

Based on the results of the research, analysis of discussions and conclusions, several suggestions can be made as follows:

1. Making a science process skills assessment requires a team, so that the questions developed are more creative and varied.

2. Making science questions based on science process skills needs more references, so that the questions developed can produce good quality questions.

\section{REFERENCES}

Bambang Sumintono dan Wahyu Widhiarso. (2015). Aplikasi Pemodelan RASCH pada Assessment Pendidikan Cimahi: Trim Komunikasi.

Beaumont-Walters, Y., \& Soyibo, K. (2001). An Analysis of High School Students' Performance on Five Integrated Science Process Skills. Research in Science \& Technological Education, 19(2), 133-145.

Dharmawati, D., Rahayu, S., \& Mahanal, S. (2016). Pengembangan Instrumen Asesmen Berpikir Kritis untuk Siswa SMP Kelas VII pada Materi Interaksi Makhluk Hidup dengan Lingkungan. Jurnal Pendidikan: Teori, Penelitian, Dan Pengembangan, 1(8), 1598-1606.

Farhan, M., \& Retnawati, H. (2014). Keefektifan PBL dan IBL Ditinjau dari Prestasi Belajar, Kemampuan Representasi Matematis, dan Motivasi Belajar. Jurnal Riset Pendidikan Matematika, 1(2), 227-240.

Fitri, J., \& Sa'adah, S. (2019). Penguasaan Konsep Siswa pada Materi Ekosistem melalui Penerapan Model Problem Posing Learning Berbasis Dongeng Sains (Ppl-Ds). Jurnal Bioeduin: Program Studi Pendidikan Biologi, 9(1), 63-70.

Kartika, A. T., Eftiwin, L., Lubis, M. F., \& Walid, A. (2020). Profil Kemampuan Berpikir Kritis Siswa Kelas VIII SMP pada Mata Pelajaran IPA. Jurnal Riset Teknologi dan Inovasi Pendidikan (JARTIKA), 3(1), 1-10

Reddy, V., Visser, M., Winnaar, L., Arends, F., Juan, A. L., Prinsloo, C., \& Isdale, K. (2016). TIMSS 2015: Highlights of Mathematics and Science Achievement of Grade 9 South African Learners.

Risti, V. (2018). Pengembangan Asesmen IPA Berbasis Keterampilan Proses Sains pada Materi Interaksi Makhluk Hidup dengan Lingkungan Kelas VII di SMP Islam AzZahrah 2 Palembang (Doctoral Dissertation, Uin Raden Fatah Palembang).

Roheni, A., Sutresna, Y., \& Ilmiyati, N. (2020). Penerapan Model Pembelajaran Discovery Learning untuk Meningkatkan Sikap Ilmiah dan Keterampilan Proses Sains Siswa Pada Sub Materi Pola Interaksi Manusia Mempengaruhi Ekosistem. Bioed: Jurnal Pendidikan Biologi, 8(2), 40-45.

Sabda, Syarifuddin. Model Kurikulum Terpadu Iptek dan Imtek. Ciputat Press Group 2006

Sari, H. K. (2016). Peningkatan Keterampilan Proses Sains dan Hasil Belajar Fisika Siswa pada Model Pembelajaran Kooperatif Tipe Student Team Achievement Division. Tadris: Jurnal Keguruan Dan Ilmu Tarbiyah, 1(1), 15-22. 
Setiawan, D. (2017). Pendekatan Saintifik dan Penilaian Autentik untuk Meningkatkan Mutu Pembelajaran Pendidikan Agama Islam. Al-Asasiyya: Journal of Basic Education, $1(2)$.

Stadler, M., Herborn, K., Mustafić, M., \& Greiff, S. (2020). The Assessment of Collaborative Problem Solving in PISA 2015: An Investigation of The Validity of The PISA 2015 CPS Tasks. Computers \& Education, 157, 103964.

Sugiyono, P. Dr. (2017), Metode Penelitian Pendidikan: Pendekatan Kuantitatif, Kualitatif, R\&D. Cetakan Ke-25. Bandung: CV Alfabeta.

Tawil, M., \& Sari, L. (2014). Keterampilan-keterampilan sains dan implementasinya dalam pembelajaran IPA. Makasar: Badan Penerbit Unm.

Usmeldi. (2016). Pengembangan Asesmen Keterampilan Proses Sains Pada Pembelajaran Fisika Berbasis Riset. Proseding Seminar Nasional Fisika dan Aplikasinya. 5. 236244.

Walid, A., Putra, E. P., \& Asiyah, A. (2019). Pembelajaran Biologi Menggunakan Problem Solving Disertai Diagram Tree Untuk Memberdayakan Kemampuan Berpikir Logis Dan Kemampuan Menafsirkan Siswa. IJIS Edu: Indonesian Journal of Integrated Science Education, 1(1), 1-6.

Wati, W., \& Novianti, N. (2016). Pengembangan Rubrik Asesmen Keterampilan Proses Sains pada Pembelajaran IPA SMP. Jurnal Ilmiah Pendidikan Fisika Al-Biruni, 5(1), 131140.

Wulansari, D. (2017). Pengembangan Instrumen Asesmen Keterampilan Proses Sains Pada Materi Sistem Koloid, di akses pada 29 November 2020.

Zahro, T., \& Widodo, W. (2019). Keterlaksanaan Pembelajaran Menggunakan Komik Berbasis Etnosains Pada Materi Pemisahan Campuran Untuk Melatihkan Kemampuan Literasi Sains Siswa. Pensa E-Jurnal: Pendidikan Sains, 7(2) 